\title{
Structural Problems Facing the German Insurance Industry
}

\author{
by Georg Büchner *
}

Being managers of fortune we insurers are living on the art of calculating risks. This art finds its expression in the assessment of insurance premiums. Against payment we relieve our private and commercial clients of risks so that they may be able to plan more safely their private and business lives. At the same time, however, we have to consider our own security. Therefore, the price of the insurance cover is the result of a compromise - the compromise between our readiness to run risks and our need for security. There are several classes of business where our compromises are no longer correct. The gap between claim payments and calculated premiums is getting wider and wider. Red figures in many classes of business. The householders' comprehensive insurance, the theft and burglary insurance and the motor vehicle partial insurance are in need for reestablishment. The stabilization measures initiated in the industrial fire and marine insurance produce their effects more slowly than desirable.

Have the insurers who are firmly tied to venerable mathematical principles made a big mistake in their calculations ? Have we - to quote H. G. Wells - forgotten to erect dikes and trusted too much in the flood becoming reasonable? The figures indeed are depressing. In 1981, according to official data, we could register a surplus of only $0.2 \%$ of premiums earned for own account. This means in practice most companies sustained in part heavy losses in the underwriting business. In 1982 the situation is more likely to have deteriorated than to have improved. The extent the decline in profits has reached only becomes apparent if compared with the profit percentages of previous years which after all were $3.7 \%$ of premiums earned in 1975 and still 2.7 in 1979. Being managers of fortune and far-sighted businessmen it becomes unsound to continuously trust in our balances being offset by the yields on the general business which mainly depends on capital investments.

\section{Problematic "risk of change"}

If it's got harder to earn money it's not due to a failure of our mathematicians. There simply is a limit to the calculation of risks. It's true that the so-called hazardous risk is under our control, especially with homogeneous and large portfolios; on the basis of our statistics and experience we are able to calculate it quite exactly. The case is different, however, when the so-called risk of change is concerned, i.e. when the

* President of "Gesamtverband der Deutschen Versicherungswirtschaft e.V." (GDV), and "Vorsitzender des Vorstands" of "Württembergische Feuerversicherung AG", Stuttgart. 
risk factors are affected by changes in the social, political, economic, legal or technological field. This is out of our control. Many things have been in motion in the last few years, in a process which sometimes has been unforeseeable, in most cases inevitable and all in all downward. I know well enough that we are liable to the risk of error, too, but it surely is not too daring an assumption that this risk grows pale beside the effects of the risk of change and the long-term developments involved. Some examples :

- The cycles of technological innovation are getting shorter, which on the one hand makes the calculation in the commercial business more difficult and on the other hand affects the management and the marketing of insurers. The advance in the plastics field, for example, has greatly changed the appreciation of the fire risk. While in former times we only had to indemnify direct damages we nowadays pay millions for consequential loss because burning plastics set free toxic vapours which destroy or damage the equipment. The widesrpead use of water-bearing machines in private households has no more remained without consequences than the use of new materials for water pipes with the result that we will be faced with a tremendous increase in the number of pipe bursts in dwellings.

- A broad field opens with regard to the risk of social changes. The erosion of the concept of ownership, the habit of skimming the cream off at the expense of others, the widespread mentality of making excessive demands, the frightening rise of the crime rate, of violence, of vandalism, of fire caused by arson and by negligence and certainly the radical change in the understanding of the roles of men and women as well as the changed attitudes to life of our youth - all this doesn't spare us and destroys our mathematical calculations especially with regard to longterm contracts. Who could really know in the sixties that ten years later bicycles would be such a favoured target for thieves ? Never could it be foreseen that one day burglary and robbery would account for nearly $50 \%$ of the claim expenditure in the householders' comprehensive insurance on contents. Fairly often we are blamed for always painting a gloomy picture of things and for proceeding overcautiously. I think the wretched state of some insurance classes contributes at least to weaken this reproach. Perhaps we have been too confident that negative claim tendencies would peter out or at least be only temporary. It seems to me that rather often and much too long our hopes have been stronger than our experiences and our fears.

- In the middle of the year when the value added tax will be increased, we will see how the legislator acts upon the risk of change. This will necessarily entail an increase in our claim payments. The duplication of the value added tax which became effective at the beginning of 1982 for the self-employed professions and which increased the cost of claims by $5.5 \%$, is still fresh in the memory of our legal expenses insurers. Only one year before a bill was passed which provided a general increase in layers' fees. As a result of this the claim expenses rose by $13.6 \%$.

- The new regulations governing doctors' fees (GOA), however, probably have improved the general conditions for our private sickness insurers from early 1983. The new GOA which replaced the old scale dating back to 1965 regulates the remuneration of doctors for the treatment of nine million private patients. The 
numerous new regulations increase the transparency of the doctor's bills in accordance with an improved "consumer protection"; getting a higher remuneration doctors are motivated to intensify their personal medical benefits and the private sickness insurance gets a chance to hold down costs. Unfortunately it happens very rarely that legislation has a favourable effect on the risk of change as it has been the case with the new regulations governing doctors' fees.

- A most pressing risk of change, which we are trying to face with our information and public relations policy, with negociations and with patience is confronting us in quite a number of tendencies labelled "consumer protection". I don't want to dwell on the fact that in this field there are false advisers, too, suggesting for example to their listeners, television viewers and readers that insurance contracts simply could be disregarded because they allegedly violate the ordinance on price quotation (Preisangabenverordnung). Now the courts have put an end to this humbug.

Nevertheless the authors of this suggestion don't shrink from going on quoting the Federal Finance Minister as a chief witness of their opinion, though he not only raised a formal contradiction but even asked for a rectification of this statement in public. And when these people even say, as they recently did, "Life assurance for the purpose of making provision for old age is mere swindle ", I cannot, much as I try, recognize the minimum of fairness necessary to settle the quarrel in a realistic manner.

\section{Contradictory expectations placed on the Insurers}

Whatever reproaches our critics may have to advance against us, they surely cannot blame us for not taking them seriously. The insurers live on people trusting them and every insurance contract is in the first place a token of the confidence which their clients set in them. Thus we have to make things clear, when people try to make a fool of us. Much of what the public - including the politicians - wishes and requires of us, is at first sight quite understandable but often enough not thought through. Contradictions become apparent :

- We are supposed to reduce the costs, but not at the expense of jobs.

- We are supposed to provide permanent security, but to maintain stable premiums.

- The motor insurers are supposed to help the victim quickly and without red-tape, but at the same time they are expected to keep up the driver's reputation and to save his no-claims discount.

- The insurance conditions are to be complete, unequivocal and equitable as well as simple and easy to grasp.

- The capital investments of life assurers are expected to yield a high profit for the benefit of the policyholders without the engagement in apartment house construction being neglected.

- In life assurance the policyholder wants higher surrender values, but of course the big number of loyal clients must not be penalized by the corresponding reduction of surpluses. 
- People want us to be generous and to make ex gratia settlements without the premiums being increased. Everybody expects us to prevent fraud and abuse, but when he corrects his own case in his favour, we are expected to be lenient.

- Our advisory service is to be complete and close at hand, but with no costs if possible.

- We had better dispense with contracts with a duration of more than one year, but in no case should we charge a higher price for one-year contracts.

- We are to tighten competition but we should avoid bankruptcies leaving clients' claims unsatisfied and killing jobs.

The list of wishes, a register of contradictions, could be prolonged at will. I think, people overestimate us and our possibilities. Because our product "insurance" has much to do with mathematics, people probably think we are capable to make the circle a square. Not that we smile at our critics. There is nearly no limit to our capacity to learn. But where there are fathomless contradictions, things don't promising as far as feasibility is concerned. Far too often the lack of knowledge of economic problems and still more of insurance problems is shining through. This is something which economy in general is suffering from. The financial editors can equally tell about how hard it is to interest the average reader in news and commentaries.

If $I$ bring to my mind the result of a simple inquiry according to which only $21 \%$ of the population classified statements of politicians and journalists on economic and social policy as "mostly understandable", the half as "now and then understandable" and $19 \%$, that is 10 million citizens of the Federal Republic, as "gibberish", I am reminded of a word of my collegue, Professor Dr. Reimer Schmidt, who so to speak attested to the consumer the constitutional right to be not informed. The figures concerning our industry are rather even more negative. People know about the gaps in their knowledge, but are not particularly willing to fill them. On the other side a study made by the German Insurance Association (GDV) has shown that those who are well informed want to know more about insurance, that is about other types of insurance as well as about details.

\section{Publicity and supervision}

An invisible commodity, on top of it a product of mathematics and law, cannot fascinate by beauty, which - contrary to virtue - needs no evidence. What one cannot "grasp" in the true sense of the word, doesn't exactly evoke any sensation of pleasure but rather distrust. No wonder that people demand many virtues from us and put us to the test again and again. Some critics keep calling for more State and supervision, others expect even more competition as a result of less State action.

No doubt about it : competition without State intervention would have to be quite different from that existing when a State agency takes care of the insurance conditions, of the personal and professional qualification of the directors, of the financial soundness and sufficient solvency as well as of the profitability of real estate bought by the company and of the buildings constructed on it, and last but not least of the costing and 
cost accounting. It's exactly to the advantage of the consumer protection that in this country we don't emphasize primarily the competition with regard to conditions ; all the more intensive are the efforts to solicit clients in the field of prices and services. The competition between the different forms of undertakings - companies limited by shares, mutual associations, insurance institutions under public law - contributes furthermore to provide the consumer with a satisfactory insurance cover without his having to worry about the insurer's capacity to meet his claims. The technical losses in fire and marine insurance - meanwhile amounting to billions - for example, would certainly not have incurred had there been a lack of competition.

Quite recently doubts as to whether competition between insurers would be sufficient were expressed in a study made in Berlin. The author criticized the existing material State supervision and speaks in favour of a pure solvency control. Doing this he disregards the following point : The supervisory authority has to fulfill the task assigned to it by the State, namely to protect the interests of the insured and to guarantee that insurance contracts can always be carried out. After the war there were some dozens of bankruptcies of insurance companies in Great Britain which caused great damage to the insured. This was quite recently pointed out by the President of the Federal Supervisory Authority for Insurance (BAV). There is no argument whatsoever which can be put forward to prove that our motor insurance is too expensive. Particularly in this class, for reasons of competition, all possible cost economies are passed on to the client, in the first place by benefits to policyholders. The considerable shifts which took place in the market during the last ten years are keenly felt by many a company as a result of an extremely severe and still increasing competition.

In principle we insurers consider the State supervision by the BAV as reasonable ; it is best capable to protect the consumer. We accept that again and again this system induces politicians to take actions as if they owe it to themselves and to their voters to be constantly changing something only to keep the consumerism's flag flying. During the past we had to accept many a fly in the ointment and in no way the consumer always was the real winner. We have reason to fear that this will not change in the future. Our law governing the supervision of insurance keeps being modified, enlarged, adjusted ; one amendment is following the other. Thereby the intensity of supervision necessarily increases. Continuous modifications of the basic conditions, however, don't fail to affect the management of the companies, the accounting system which anyway is complicated enough, and the conditions of the industry as a whole.

The German Bundestag recently passed the 14th Amendment to the Law governing the supervision of insurance (14. Novelle zum Versicherungsaufsichtsgesetz) which not only introduced the EEC Life Establishment Directive and the Non-Life Coinsurance Directive into German law but also was supplemented - without Brussels helping by some dispositions such as the introduction of a "return ratio" in life assurance, the effects of which remain to be seen.

In our country the interests of the consumer are protected not least by the cartel legislation. The supervision of cartels has been intensified by the new version of $\S 102$ GWB (Law governing competition) contained in the 4th amendment to the Cartel Law and as a result of this transactions within the scope of cartel regulations have been made much more transparent than in other sectors of economy. Thus the insurers are obliged to disclose each and every measure apt to restrict competition and to justify 
such measures. In this way the insurance buyer, too, is early informed about the establishment of rates and conditions. There are additional regulations supplying the Cartel Authority with another instrument to effect right at the beginning a detailed verification of all steps taken by the insurers. Not last the combined action of insurance supervision and of cartel supervision prevents that competition in insurance is restricted to the detriment of the consumer without any reasonable justification.

Whoever speaks of the insufficiency of competition mentions in the same breath the alleged lack of transparency. But what about transparency if our conditions of insurance were not subject to approval ? The comparability of products and prices would be threatened all the more. Then we could justly speak of a confusion, of insurance coverage being sold under a false label of "perforated as a Swiss cheese" as someone once put it justly. Exactly because transparency is a high value in our opinion, we are supporting it in Brussels. We want that for the German consumer the approval of conditions is maintained at least in the bulk business. We think that a compromise can be found by the way that a foreign insurer may immediately take up his business upon the expiry of a period of six months from the date of filing the conditions with the Federal Supervisory Authority even though the BAV has not yet granted the approval within this period. With regard to industrial and commercial risks a solution is beginning to take shape according to which the foreign insurer has to submit his conditions to the supervisory authority before taking up his business but he may begin his activity immediately without having to wait for the verification by the BAV being effected.

Our critics always find it difficult to take due note of the intense and imaginative competition in the field of services and to appreciate it to its full value. While they just recognize the advisory activity of the field service staff after the insured event has occurred, they are rather sceptical about the individual advice given upon entering the contract. The servicing during the contract period - when there are changes affecting the household and the family, when the apartment or the car is changed or in case of under-insurance and product changes - seems to be considered rather as mere theory than as the rule. Everybody readily believes a lawyer or a doctor that he has to keep himself informed on the laws and scientific findings. However, people hardly ever think that our field service staff has to improve their knowledge, too, and that they would quickly be lagging behind without a continuous effort to study and to master an enormous flow of information. A field service staff member who looses his firm grip of things, will soon have difficulties to hold his stand against his clients, which will be felt very quickly on the income side. Therefore, the companies are spending sums amounting to millions for the information and training of their staff members, for life-long learning. Just as we have to stand up against competition day by day, we are challenged when we try to sell our invisible commodity in the present phase of stagnation which has been the longest after the war. The decrease of private income and frightening news from the labour market don't exactly encourage longterm commitments such as insurance contracts. As to the commercial business it is extremely lacking of the conditions necessary for writing new business because of the restricted investment activity, the continuing weakness of the order positions and the more difficult export trade. However, compared with other economic sectors we are still lucky. During the last years the premium growth has only slowed down from $9.4 \%$ 
to almost $7 \%$. With an income of nearly 91 billion DM the private insurance surely remains below the turnover of the housing, food and car industries for example, but it lies not less clearly ahead of such important sectors as the iron and steel producing industry, the textile and clothing industry. On the other hand, the premium income of social sickness insurance alone exceeds that of the entire private insurance industry. According to statistics each citizen of the Federal Republic of Germany spends about 1,500 DM a year for private and commercial insurance cover - with an average of six policies. The per-head expenses for health care - including the indirect expenses going to institutions of the health sector - amount to about 3,500 DM according to a calculation by the Federal Statistical Office. Considering the fact that medical expenses have tripled within 10 years it becomes apparent to what extent the legislator has restricted the citizens' - of all income groups - possibilities to take care of their own provision for economic security and welfare.

At the beginning of the year 1983 we presumably had some 370 million contracts in force, 67 millions of which are life assurance policies. In 1982 private insurance has been able to consolidate its position as a reservoir of capital resources. The capital funds invested amounted to about 350 billion DM - including pension and funeral expenses funds and reinsurance. Much more than $70 \%$ of the investment resources are for the benefit of the provision for old age, first of all through life assurance.

Once again it proves to be true that the citizen doesn't think of putting himself on a starvation diet as far as his personal protection is concerned. As a matter of fact he moderates his demands in this respect only if it comes to the worst. Our clients - and nearly everybody in this country is one of them - have recognized the value of the individual's private provision and trust in the soundness of our industry which hasn't known any crashes for decades.

The new legislation governing the tenants' protection has provided the conditions for a better supply in dwellings and for the recovery of the market. In our opinion this is a more equitable solution than the adherence to a legislation as a result of which dwellings built with subsidies from public funds are often occupied by the wrong, i.e. not needy tenants and it is virtually impossible for investors to obtain adequate yields. A return to the old tenancy legislation not only would cause a psychological havoc but also bring the apartment house building to a standstill. In the early seventies about 13,000 dwellings a year were built by the insurers. During the post-war period we financed in whole or in part more than 3 million dwellings, i.e. about every fifth during the last 3 decades. Even in the last two years the number of dwellings built and financed still amounted to 100,000 a year.

In view of the decreasing capital market rates the need of a reform of para 247 of the Civil Code (BGB) becomes more and more urgent. The insurers have put forward their proposals for long. Whether and to what extent our companies will in future tie up their capital in mortgages and other long-term loans will depend decisively on whether the "usury paragraph" which has been introduced under completely different circumstances and which is no longer up-to-date, will be reformed. The debtor's unilateral right of cancellation is a handicap to long-term loans at fixed rates of interest. During the seventies it was a bitter experience for the insurers to see that in a period of rising interest rates they were bound to the rate once agreed while, 
when the interests moved downward, the borrowers reffered to para 247 , cancelled the contract and asked for a reduced interest rate. No wonder that the insurers lately preferred to an increasing extent other investments, first of all fixed-interest securities.

The author Carl Améry once said: "The risk is the bow wave of success". But risks must remain calculable. That requires stable basic conditions as well as courage and trust in the future. We never have been lacking in courage. We have relieved investors and companies of the risks linked with technological progress and have thus made possible many an achievement which by now is nearly taken for granted in our highly-technicized society. First of all, due to the personal and liability classes of insurance, millions of private households are able to enjoy a freer and peaceful life. This, too, is part of social security. The private safety net which our clients have made voluntarily and under their own responsibility, with our help, has proved to be solid and such it will remain.

While those subject to social insurance are exposed to the inconsistencies of political tendencies, we private insurers naturally accept the responsibility for our contracts - despite all risks of change and error. 